\title{
INTERACTIVE EFFECTS BETWEEN IRRIGATION AND NITROGEN TREATMENTS ON YIELD, NITROGEN ACQUISITION AND NITROGEN USE AND AGRONOMIC EFFICIENCIES OF WHEAT PLANT \\ Mahdy, A. M. ${ }^{1,2}$; Nieven O. Fathi ${ }^{3}$ and A. E. Elnamas ${ }^{1}$ \\ 1 Dept. of Soil and Water, Fac. Agric., Alex. Univ., Elshatby, 21545, Alexandria, (Egypt), \\ 3 Salinity and Alkalinity Soils Research Laboratory, Abis-Alexandria Ministry of Agriculture and Land Reclamation, (Egypt)
}

\begin{abstract}
Field experiments were conducted to investigate the interactive effects between different irrigation treatments and $\mathrm{N}$ application rates on grain and straw yields of wheat plants grown on a clay soil and to describe the relationships between irrigation treatments and yield of wheat plants at different $\mathrm{N}$ treatments. The factors were nitrogen fertilizer $(\mathrm{N}): 0\left(\mathrm{~N}_{0}\right), 75\left(\mathrm{~N}_{1}\right), 150\left(\mathrm{~N}_{2}\right)$, and $225\left(\mathrm{~N}_{3}\right) \mathrm{kg} \cdot \mathrm{ha}^{-1}$ as urea and four treatments of irrigation(I): fully-irrigation with canal water $\left(\mathrm{l}_{1}\right), 2$ times well water + canal water $\left(\mathrm{I}_{2}\right)$, 4 times well water + canal water $\left(\mathrm{I}_{3}\right)$, and 6 times well water + canal water $\left(\mathrm{I}_{4}\right)$. The obtained results indicated that grain and straw yields were significantly increased with increasing application rate of $\mathrm{N}$ fertilizer at all treatments of irrigation. On the other hand, grain and straw yields of wheat plants were decreased significantly with increasing number of well water irrigation times. The maximum nitrogen use efficiency (NUE) for grain yield $\left(63.73 \mathrm{~kg} \mathrm{~kg}^{-1} \mathrm{~N}\right)$ was found with a $75 \mathrm{~kg} \mathrm{~N} \mathrm{ha}^{-1}$ and $\mathrm{l}_{1}$ (fully-irrigation with canal water). In contrast, the minimum NUE for grain yield $\left(19.56 \mathrm{~kg} \mathrm{~kg}^{-1} \mathrm{~N}\right)$ was found with a $225 \mathrm{~kg} \mathrm{Nha}^{-1}$ and $\mathrm{I}_{4}$ (6 times well water,4500 $\mathrm{m}^{3} \mathrm{ha}^{-1}+$ canal water, $1500 \mathrm{~m}^{3} \mathrm{ha}^{-1}$ )for first season. Similarly, irrigation with well water decreased the agronomic efficiency $(\mathrm{AE})$ for grain yield noticeably at all $\mathrm{N}$ application rates. The reduction in $A E$ for grain yield of wheat was much higher at $I_{4}$ treatment than of that at $I_{2}$ treatment. The mean agronomic efficiency $(A E)$ for grain yield for the second season confirmed the results of first season and was very close to each other. Future research works should be made by further developing more efficient wheat varieties that could use $\mathrm{N}$ more efficiently at lower rates $\left(<225 \mathrm{~kg} \mathrm{~N}^{-1}\right)$. It can be concluded that the limited amount of available fresh water should be applied during the initial growth stage and supplemented with well water at later growth stages of wheat plants.
\end{abstract}

Keywords: Agronomic Efficiency, N Acquisition, N-Use Efficiency, Well water, Wheat Yield

\section{INTRODUCTION}

Today, the competition for scarce water resources is intense throughout the world. In such water-limited conditions, wheat productivity is highly dependent on irrigation water availability and quality decline continuously as a result of climate change and increasing consumption. Irrigation water

²Corresponding author E.mail: amahdy73@ yahoo.com 
Mahdy, A. M. et al.

Irrigation water is becoming an increasingly limited resource in many areas of Egypt and consequently, an appropriate choice of irrigation scheduling in order to maximize water use efficiency and profit is needed. Moreover, in many situations, wheat is grown mainly in river basins, which are environments sensitive to underground water nitrate pollution risk. An appropriate application of irrigation water (I) and nitrogen ( $\mathrm{N}$ ) fertilizer has the vital purpose of increasing water and nitrogen productivity and reducing environmental pollution risk (English and Raja, 1996). To prevent widespread crop failure, the concept of protective irrigation implying a limited water supply to agricultural lands has been introduced. Currently, communities in most areas of Egypt are faced with water shortage, low water-use efficiency (WUE) and $\mathrm{N}$ use efficiency (NUE), and high $\mathrm{NO}_{3}-\mathrm{N}$ contamination in groundwater which often exceeds drinking-water standards (Zhang et al. 1995, 1996; Ma et al. 2005; Yang and Su 2008). It is predicted that these problems will be worse in arid regions in the future, and farmers will have to rely more on underground water and $\mathrm{N}$ fertilizer for crop production in order to feed the increasing population (Zhang et al. 1996). Crop production systems that optimize yield, reduce $\mathrm{N}$ loss and improve $\mathrm{N}$ uptake and WUE are desirable.

Nitrogen fertilizer and irrigation water are two major factors influencing wheat yield, $\mathrm{N}$ uptake and $\mathrm{N}$ loss, which can be controlled by the grower (Ottman and Pope 2000; Yin et al. 2007). Nitrogen fertilization also increases crop yield when the soil $\mathrm{N}$ supply is low (Fredrick and Camberato 1995a and b; Sexton et al., 1996). Nitrogen application rate was the main factor causing $\mathrm{N}$ loss; no $\mathrm{NO}_{3}-\mathrm{N}$ leaching was found when the $\mathrm{N}$ application was below 150 $\mathrm{kgha}^{-1}$, but $\mathrm{NO}_{3}-\mathrm{N}$ leaching increased at rates of $225-300 \mathrm{~kg} \mathrm{~N}^{-1}$ (Fan et al. 1998). Grain yield of wheat, harvest index and NUE reached their highest at an application rate of $225 \mathrm{~kg} \mathrm{~N} \mathrm{ha}^{-1}$. The economic yield is maximum at an application rate of $150-225 \mathrm{~kg} \mathrm{~N}^{-1}$ (Li et al., 2001). The partial fertilizer productivity (PFP-grain yield per unit applied $\mathrm{N}$ ) of applied $\mathrm{N}$ fertilizer decreased significantly when $\mathrm{N}$ fertilizer input exceeded $200 \mathrm{~kg} \mathrm{~N} \mathrm{ha}^{-1}$ for wheat production ( Fang, et al., 2006).In general, increased soil water content enhances crop yield response to $\mathrm{N}$ fertilization, especially when high $\mathrm{N}$ rates are applied (Norwood 2000). In addition, N uptake is strongly influenced by water supply. High $\mathrm{NO}_{3}{ }^{-}$leaching occurs with high rainwater and irrigation water supply (Fang, et al., 2006). In a sub-Saharan environment, Pandey et al. (2001) reported a linear yield response to irrigation at all $\mathrm{N}$ levels.

Generally, the greater the N supply, the more yield was reduced by deficit irrigation. O'Neill et al.(2004) reported a greater yield response with $\mathrm{N}$ application under adequate soil water conditions, and a lower one under deficit water conditions. They also reported an average yield increase of $23 \%$ for adequate versus deficit water supply, and around 100\% for adequate versus deficit N levels in the Great Plains of the United States. Appropriate application of irrigation water and $\mathrm{N}$ fertilizer has dual vital purposes of increasing water and $\mathrm{N}$ productivity and reducing environmental pollution risk (Katterer et al., 1993; Su et al., 2007).

Many studies have been carried out to investigate the effects of $\mathrm{N}$ application rates on grain yield and overall $\mathrm{N}$ balance in the soil (Liu et al. 
2001, 2003; Ju et al. 2003,2004). Literature on the effects of water and nitrogen on yield and related parameters such as nitrogen use efficiency (NUE), water use efficiency (WUE) and irrigation water use efficiency (IRRWUE) are reported by Dag delen et al. (2006), Oktem et al.(2003), Evett et al. (2000, 2001), Howell et al. (1998) and Howell (2001). Such studies can provide insight into the knowledge on how deficit irrigation and $\mathrm{N}$ rates can be manipulated for spring wheat grown on recently reclaimed sandy farmland. This can maximize grain yield, improve $\mathrm{N}$ uptake and minimize $\mathrm{N}$ loss in sandy soil. The field experiment was designed to investigate the interactive effects between different irrigation treatments and $\mathrm{N}$ application rates on grain and above-ground biomass yields in a clay soil and to describe the relationships between irrigation treatment and yield of wheat plants at different $\mathrm{N}$ treatments.

\section{MATERIALS AND METHODS}

\section{Climate and soil characteristics:}

Two field experiments were conducted at the experimental farm, Soil Salinity and Alkalinity Laboratory, Ministry of Agriculture and Land Reclamation (MALR) at Abis-Alexandria, during the growing seasons: November-April 2008/2009 and 2009/2010. The geographical position is at latitude $31^{\circ} 2^{\prime \prime} \mathrm{N}$, and longitude $29^{\circ} 6 " \mathrm{E}$ with an elevation of about $2.50 \mathrm{~m}$ below sea level. The mean annual rainfall was $200 \mathrm{~mm}$ and the relative humidity during daytime is about $67.30 \%$. The mean temperature, during November and October, ranged between $23^{\circ} \mathrm{C}$ and $15^{\circ} \mathrm{C}$.

The soil chemical and physical properties were determined as follows: The $\mathrm{pH}$ was measured in 1:2.5 soil water suspension and the electrical conductivity(EC) was measured in saturated soil-paste extract (Richard, 1954);organic matter by dichromate oxidation method (Nelson and Sommers, 1982); cation exchange capacity (CEC) by IM neutral NaOAc method (Rhoades, 1982); total calcium carbonate by a calcimeter method (Nelson, 1982);available $\mathrm{P}$ by $0.5 \mathrm{M} \mathrm{NaHCO}$ test (Olsen and Sommers, 1982);available nitrogen by $2 \mathrm{M} \mathrm{KCl}$ method (Bremner and Mulvaney, 1982);available potassium by $1 \mathrm{~N}$ neutral ammonium acetate method (Knudsen and Peterson,1982); particle size distribution by the hydrometer method (Day, 1965); and the bulk density by clod method (Tan,1996). The soil chemical and physical properties are presented in Table (1). It is clear that the soil had a clay texture with $431.67 \mathrm{gkg}^{-1}$ clay, $322.33 \mathrm{gkg}^{-1}$ silt and $246 \mathrm{gkg}^{-1}$ sand.

\section{Experimental design:}

The experimental set-up was randomized complete block design with four replicates and thirteen treatments for $\mathrm{N}$ fertilizer rates and irrigation treatments. Plot size was $9 \mathrm{~m}^{2}$. The factors were nitrogen fertilizer at rates of $0\left(\mathrm{~N}_{0}\right), 75\left(\mathrm{~N}_{1}\right), 150\left(\mathrm{~N}_{2}\right)$, and $225\left(\mathrm{~N}_{3}\right) \mathrm{kg} \cdot \mathrm{ha}^{-1}$ as urea and four treatments of irrigation: fully-irrigation with $6000 \mathrm{~m}^{3} \mathrm{ha}^{-1}$ canal water $\left(l_{1}\right), 2$ times well 
water $\left(1500 \mathrm{~m}^{3} \mathrm{ha}^{-1}\right)+4500 \mathrm{~m}^{3} \mathrm{ha}^{-1}$ canal water $\left(\mathrm{I}_{2}\right), 4$ times well water $(3000$ $\left.\mathrm{m}^{3} \mathrm{ha}^{-1}\right)+3000 \mathrm{~m}^{3} \mathrm{ha}^{-1}$ canal water $\left(\mathrm{I}_{3}\right)$, and 6 times well water $\left(4500 \mathrm{~m}^{3} \mathrm{ha}^{-1}+\right.$ $1500 \mathrm{~m}^{3} \mathrm{ha}^{-1}$ canal water $\left(\mathrm{I}_{4}\right)$. The mineral nitrogen fertilizer was applied in two equal doses: before sowing and 21 days after sowing wheat seeds( Triticum aestivum c.v. Sakha 94). The phosphorus and potassium fertilizers were applied to the soil before sowing. The applications of $\mathrm{N}$ fertilizer rates and irrigation treatments yielded a total of thirteen treatments:

$\mathrm{N}_{0} \mathrm{l}_{1}: 0 \mathrm{~kg} \mathrm{~N} \cdot \mathrm{ha}^{-1}+$ fully-irrigated with canal water $\left(6000 \mathrm{~m}^{3} \mathrm{ha}^{-1}\right)$

$\mathrm{N}_{1} \mathrm{I}_{1}: 75 \mathrm{~kg} \mathrm{~N} \cdot \mathrm{ha}^{-1}$ + fully-irrigated with canal water

$\mathrm{N}_{2} \mathrm{I}_{1}: 150 \mathrm{~kg} \mathrm{~N} \cdot \mathrm{ha}^{-1}$ + fully-irrigated with canal water

$\mathrm{N}_{3} \mathrm{l}_{1}: 225 \mathrm{~kg} \mathrm{~N} \cdot \mathrm{ha}^{-1}+$ fully-irrigated with canal water

$N_{1} I_{2}: 75 \mathrm{~kg} \mathrm{~N} \mathrm{ha}^{-1}+2$ times well water $\left(1500 \mathrm{~m}^{3} \mathrm{ha}^{-1}\right)+$ canal water $\left(4500 \mathrm{~m}^{3} \mathrm{ha}^{-1}\right)$

$\mathrm{N}_{2} \mathrm{I}_{2}: 150 \mathrm{~kg} \mathrm{~N} \cdot \mathrm{ha}^{-1}+2$ times well water + canal water

$\mathbf{N}_{3} \mathbf{l}_{2}: 225 \mathrm{~kg} \mathrm{~N}^{-1} \mathrm{ha}^{-1}+2$ times well water + canal water

$\mathrm{N}_{1} \mathrm{l}_{3}: 75 \mathrm{~kg} \mathrm{~N} \cdot \mathrm{ha}^{-1}+4$ times well water $\left(3000 \mathrm{~m}^{3} \mathrm{ha}^{-1}\right)+$ canal water $\left(3000 \mathrm{~m}^{3} \mathrm{ha}^{-1}\right)$

$\mathbf{N}_{2} \mathbf{l}_{3}: 150 \mathrm{~kg} \mathrm{~N} \cdot \mathrm{ha}^{-1}+4$ times well water+ canal water

$\mathrm{N}_{3} \mathrm{I}_{3}: 225 \mathrm{~kg} \mathrm{~N} \mathrm{ha}^{-1}+4$ times well water+ canal water

$N_{1} 1_{4}: 75 \mathrm{~kg} \mathrm{~N} \mathrm{ha}^{-1}+6$ times well water $\left(4500 \mathrm{~m}^{3} \mathrm{ha}^{-1}\right)+$ canal water $\left(1500 \mathrm{~m}^{3} \mathrm{ha}^{-1}\right)$

$\mathbf{N}_{2} \mathbf{I}_{4}: 150 \mathrm{~kg} \mathrm{~N} \mathrm{ha}^{-1}+6$ times well water+ canal water

$\mathrm{N}_{3} \mathrm{l}_{4}: 225 \mathrm{~kg} \mathrm{~N} \cdot \mathrm{ha}^{-1}+6$ times well water+ canal water

The sources of irrigation water were canal and well (Table 2).

Plant sampling and analysis:

The plants were harvested at April 25, 2009 and 2010. The grains were separated from the whole plant. The plant samples were first washed with tap water followed by distilled water and oven dried at $75^{\circ} \mathrm{C}$ for $48 \mathrm{hrs}$. and then weighed and ground in a stainless steel mill. Sub-samples of ground plant material were dry-ashed in a muffle furnace at $450{ }^{\circ} \mathrm{C}$ for $6 \mathrm{hrs}$. and the ash was dissolved in diluted nitric acid (1:1), then diluted to a constant volume with distilled water and analyzed for total phosphorus and total potassium. Other plant sub-samples were wet-digested by sulfuric acid and hydrogen peroxide, diluted to a constant volume with distilled water and analyzed for total nitrogen (Jones, 2001).

Dry matter production of straw and grain yield is expressed on dry weight basis. Plant nitrogen uptake was calculated in first and second seasons from multiplying concentrations in grain and straw by dry matter of both.

\section{Water sampling and analysis:}

Representative water samples $(500 \mathrm{ml})$ were collected in polyethylene bottles, which properly washed/rinsed with the same water that is being sampled. Water samples were taken from two sources, the first source represents canal water, and the second represents well water. After proper labeling (e.g. source of water, date of collection, and type of analysis required), the samples were sent immediately to the laboratory. The water samples were filtered and analyzed for EC, soluble cations and anions (Richards, 1954), but the $\mathrm{pH}$ of water samples was measured before filtration of samples (Richards, 1954); Sodium adsorption ratio (SAR) was calculated 
in order to determine the sodicity or alkalinity hazard of irrigation waters. Water analysis data are presented in Table (2)

Nitrogen use efficiency:

Nitrogen use efficiency (NUE) is defined as a unit of grain produced per unit of nitrogen applied. This would mean that all the nitrogen applied was taken into consideration. The NUE was calculated by dividing the grain yield with the total amount of nitrogen applied for each treatment. The following equation was used to calculate NUE :

$$
\text { NUE }=\text { TGY/TNA }
$$

Where NUE is Nitrogen-use efficiency, TGY is total grain yield in kilograms per hectare and TNA is total nitrogen applied in kilograms per hectare.

Agronomic efficiency:

Agronomic efficiency $(A E)$ was calculated using the following equation:

$$
A E=G Y_{i}-G Y O / N_{i}
$$

Where $G Y_{i}$ and $G Y_{0}$ are grain yield at $N_{i}$ inputs and the control $\left(N_{0}\right)$, respectively.

\section{Statistical and mathematical analyses:}

The two-way analysis of variance (ANOVA) was carried out to determine the statistical significance of the treatment effects on grain or above-ground biomass yield ,nitrogen use efficiency, agronomic efficiency, and nitrogen acquisition, with the Fisher's least significant difference procedure at a significant level of 0.05 (SAS Institute, 1994). The polynomial quadratic model was used to describe the relationship between units of irrigation with well water and grain and above-ground yields of wheat plants grown on soils treated with different rates of nitrogen fertilizer.

The polynomial quadratic model used is in the form:

$$
Y_{i}=a+b X_{i} \pm C X_{i}
$$

Where $Y_{i}$ is the expected grain or above-ground biomass yields corresponding to units of irrigation with well water $X i$ at each $\mathrm{N}$ rate, $a$ is the intercept, $b$ and $C$ are the linear and quadratic coefficients, respectively.

The maximum yield and maximum applied irrigation unit for all nitrogen treatments were calculated as follows:

$$
\begin{gathered}
Y_{\max }=a-\left(b^{2} / 4 C\right) \\
I_{\max }=-b / 2 C
\end{gathered}
$$

Where $Y_{\max }$ is the maximum grain or above-ground biomass yields corresponding to units of irrigation with well water $\left(I_{\max }\right)$ at nitrogen rate, $a$ is the intercept and $b, C$ are the linear and quadratic coefficients, respectively.

\section{RESULTS}

\section{Soil and water characterization:}

The experimental soil was classified as a clay soil (Typic Torrifluvents) with a relatively medium total carbonate $\left(61.04 \mathrm{gkg}^{-1}\right)$ and poor in organic matter content $\left(16.00 \mathrm{~g} \cdot \mathrm{kg}^{-1}\right)$. Implying any crop and soil differences experienced during the experiments may be attributed to the treatment and not to soil heterogeneity. The electrical conductivity of soil is relatively low 
Mahdy, A. M. et al.

$\left(1.87 \mathrm{dSm}^{-1}\right)$ and below $4 \mathrm{dSm}^{-1}$ and the value of CEC of the soil indicates its ability to supply cationic nutrients for plant growth (Table 1 ).

Table (1): The main physical and chemical characteristics of the field experimental soil ${ }^{a}$

\begin{tabular}{|c|c|c|}
\hline Characteristics & Unit & Value \\
\hline Sand & $\mathrm{g} \mathrm{kg}^{-1}$ & $244.00 \pm 5.29$ \\
\hline Silt & $\mathrm{g} \mathrm{kg}^{-1}$ & $324.54 \pm 2.52$ \\
\hline Clay & $\mathrm{g} \mathrm{kg}^{-1}$ & $431.46 \pm 4.69$ \\
\hline Soil Texture & $\mathrm{Kg}^{-3}$ & Clay \\
\hline $\mathrm{D}_{\mathrm{b}}$ & $\mathrm{dSm}^{-1}$ & $1350 \pm 11.00$ \\
\hline $\mathrm{EC \dagger}$ & & $1.87 \pm 0.12$ \\
\hline $\mathrm{pH}(\mathrm{range}) \ddagger$ & $\mathrm{g} \mathrm{kg}^{-1}$ & $7.70-8.08$ \\
\hline Total CaCO & $\mathrm{g} \mathrm{kg}^{-1}$ & $61.04 \pm 3.56$ \\
\hline $\mathrm{O}^{\dagger} \mathrm{M}^{\dagger}$ & ${\mathrm{Cmol}(+) \mathrm{gg}^{-1}}^{-1}$ & $16.41 \pm 0.86$ \\
\hline CEC & $\mathrm{mg} \mathrm{kg}^{-1}$ & $27.84 \pm 3.69$ \\
\hline Available-P & $\mathrm{mg} \mathrm{kg}^{-1}$ & $10.55 \pm 0.43$ \\
\hline Available- $\mathrm{N}$ & $\mathrm{mg} \mathrm{kg}^{-1}$ & $14.24 \pm 0.89$ \\
\hline Available-K & & $132.85 \pm 6.43$ \\
\hline
\end{tabular}

Data are the samples

\pm standard deviation except for $\mathrm{pH}$

$\dagger$ in soil paste extract

$\ddagger$ in soil paste

As compared with the USEPA (1993), for maximum allowed irrigation water criteria, the data presented in Table (2) showed an increase in soluble ions, except for $\mathrm{Ca}$ and $\mathrm{Mg}$, and SAR in well water as compared to canal water. The EC of well water was more than $3 \mathrm{dSm}^{-1}$. The concentrations of chloride, sodium and bicarbonate, and the value of SAR were more than the US EPA allowed irrigation water criteria.

Table (2): The chemical analysis of the irrigation waters used in the study (means \pm SD except for $\mathrm{pH}$ ).

\begin{tabular}{|c|c|c|c|c|c|c|c|c|}
\hline \multirow{2}{*}{$\begin{array}{c}\text { Sources } \\
\text { of } \\
\text { Irrigation } \\
\text { Water }\end{array}$} & \multirow[b]{2}{*}{$\begin{array}{l}\mathrm{EC} \\
\mathrm{dSm}^{-1}\end{array}$} & \multirow[b]{2}{*}{ pH } & $\mathrm{Na}^{+1}$ & $\mathrm{Ca}^{+2}$ & $\mathrm{Mg}^{+2}$ & $\mathrm{Cl}^{-1}$ & $\mathrm{HCO}_{3}^{-1}$ & SAR \\
\hline & & & \multicolumn{6}{|c|}{ meql $^{-1}$} \\
\hline Canal & $0.62 \pm 0.05$ & 7.19 & $2.78 \pm 0.10$ & $1.09 \pm 0.050$ & $0.52 \pm 0.03$ & $2.30 \pm 0.73$ & $4.20 \pm 0.20$ & $3.12 \pm 0.18$ \\
\hline Well & $4.39 \pm 0.11$ & 8.17 & $39.00 \pm 0.70$ & $1.22 \pm 0.090$ & $2.48 \pm 0.45$ & $25.00 \pm 1.62$ & $7.00 \pm 0.87$ & $28.67 \pm 2.34$ \\
\hline IWC $^{b}$ & 3.00 & $6.50-9.00$ & 3.00 & 20.00 & 5.00 & 10.00 & 1.50 & $6-12$ \\
\hline
\end{tabular}

' IWC: Irrigation water criteria, US EPA 1992

\section{Grain and straw yields:}

Grain and straw yields were significantly increased $(P<0.05)$ with increasing application rate of $\mathrm{N}$ fertilizer at all treatments of irrigation in the two successive seasons (Fig. 1).The average high grain yield was $5970 \mathrm{~kg}$ $\mathrm{ha}^{-1}$ at $\mathrm{N}_{3} \mathrm{l}_{1}$ (225 kg N. ha- ${ }^{-1}$ and fully irrigated with canal water), while the lowest was $1840 \mathrm{~kg} \mathrm{ha}^{-1}$ at $\mathrm{N}_{0} \mathrm{l}_{1}$ in first season. The same trend was observed 
for straw yield and the values were 7120 and $2200 \mathrm{~kg} \mathrm{ha}^{-1}$ at $\mathrm{N}_{3} \mathrm{l}_{1}$ and $\mathrm{N}_{0} \mathrm{l}_{1}$, respectively. Similarly, grain and straw yields of wheat were decreased significantly $(P \leq 0.05)$ with increasing number of well water irrigation times (Fig.1).Irrigation with well water, however, decreased the grain yield noticeably $(P \leq 0.05)$ from $5970 \mathrm{~kg} \cdot$ ha $^{-1}$ at $\mathrm{N}_{3} \mathrm{l}_{1}$ to $4400 \mathrm{~kg} \cdot \mathrm{ha}^{-1}$ at $\mathrm{N}_{3} \mathrm{l}_{4}(\mathrm{Fig} .1)$ in first season.

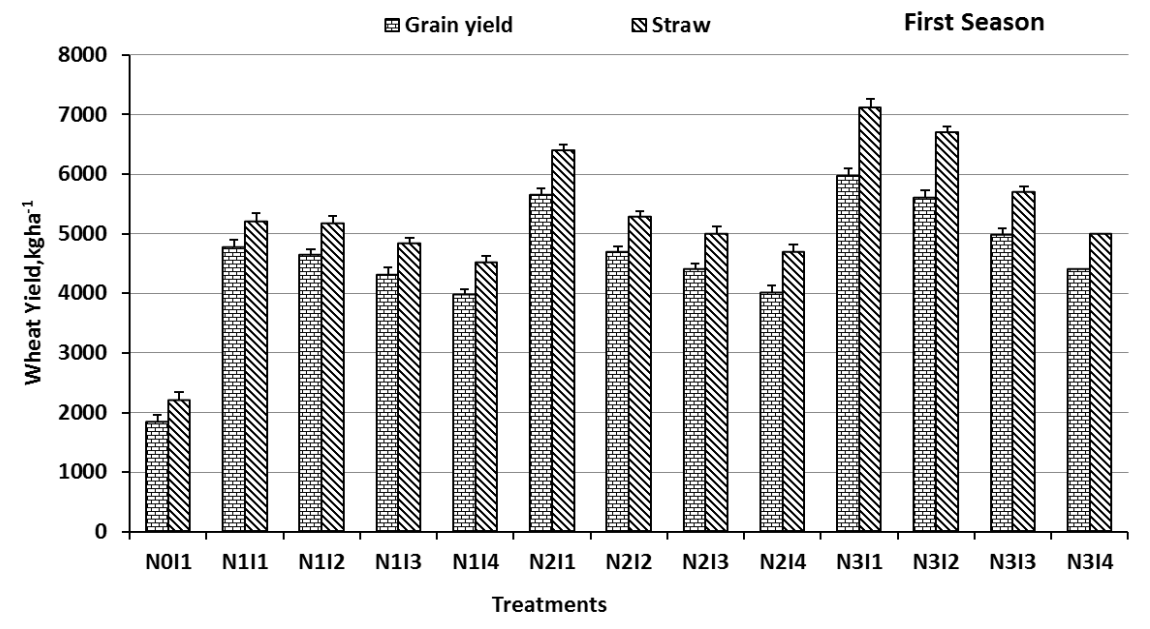

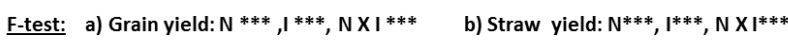

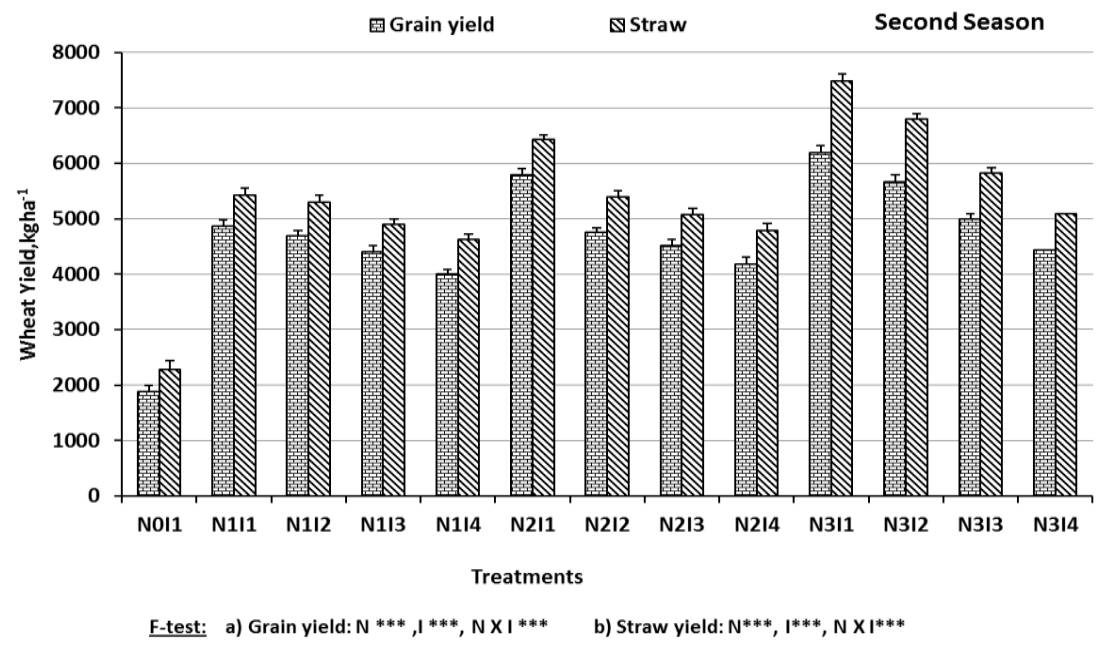

Fig.1: Grain and straw yields of wheat plant grown on soil treated with different treatments of $\mathbf{N}$ fertilizer and irrigation in two successive seasons. 
The same trend was found at $\mathrm{N}_{1} \mathrm{l}_{1}$ and $\mathrm{N}_{1} \mathrm{l}_{4}$, and $\mathrm{N}_{2} \mathrm{I}_{1}$ and $\mathrm{N}_{2} \mathrm{I}_{4}$ (Fig.1).The reduction in grain and straw yields of wheat were much higher at $I_{4}$ than at $I_{2}$. The reduction percentages were $3 \%, 10 \%$, and $17 \%$ at $I_{2}, I_{3}$, and $\mathrm{I}_{4}$, respectively (Fig.1). The interaction effects between $\mathrm{N}$ application rates and irrigation treatments with well water on grain and straw yields were significant $(P \leq 0.001)$ (Fig.1). These results were confirmed with the results of the second seasons.

The polynomial quadratic model was used to describe the relationship between grain and straw yields and irrigation units of well water at all $\mathrm{N}$ application rates for the two successive seasons. The method of the least squares was used to calculate the values of $B_{0}, B_{1}$ and $B_{2}$ in the polynomial model. Thus 12 polynomial quadratic models were established to express the relationship between grain and straw yields and irrigation units of well water at all $\mathrm{N}$ application rates for the two successive seasons. The eight models are shown in Figs. (2 and 3). The calculated grain and straw values were close to the experimental values as shown from the values of standard error of estimates (SE) and determination coefficient $\left(R^{2}\right)$ (Figs. 2 and 3 ). The maximum yield for grains was significantly decreased $(p<0.05)$ with increasing the number of irrigation times with well water altered with canal water at all $\mathrm{N}$ application rate (Table 3 ).

The values for maximum grain yield were 6655.93, 4015.58 and $4875.60 \mathrm{~kg}^{-h^{-1}}$ at $N_{3}, N_{1}$, and $N_{2}$, respectively. These values were corresponding to maximum number of irrigation with well water units of -2.58 , 4.40 , and -0.34 , respectively (Table 3 ). Similarly, the values for maximum straw yield were $18035.07,4936.37$ and $4232.43 \mathrm{~kg} \cdot \mathrm{ha}^{-1}$ at $\mathrm{N}_{3}, \mathrm{~N}_{1}$, and $\mathrm{N}_{2}$, respectively. These values were corresponding to maximum number of irrigation with well water units of $-40.10,-0.13$, and 3.92 , respectively (Table $3)$. These results were confirmed in the second season.

Table (3): Maximum grain and straw yields and maximum unit of irrigation for grain and straw of wheat plants grown on soil treated with different nitrogen treatments for two seasons.

\begin{tabular}{|c|c|c|c|c|}
\hline \multirow{2}{*}{ Treatments } & \multicolumn{4}{|c|}{ Maximum Yield,kg.ha ${ }^{-1}$} \\
\cline { 2 - 5 } & \multicolumn{2}{|c|}{ Grain } & \multicolumn{2}{c|}{ Straw } \\
\cline { 2 - 5 } & First season & Second season & First season & Second season \\
\hline $\mathrm{N}-75$ & 4875.60 & 5231.67 & 4936.37 & 5421.61 \\
\hline $\mathrm{N}-150$ & 4015.58 & 4728.04 & 4232.43 & 5079.09 \\
\hline $\mathrm{N}-225$ & 6655.93 & 8152.13 & 18035.07 & 8036.04 \\
\hline \multicolumn{5}{|c|}{ Maximum unit of irrigation } \\
\hline $\mathrm{N}-75$ & -0.34 & 0.70 & -0.13 & 1.07 \\
\hline $\mathrm{N}-150$ & 4.40 & 3.84 & 3.92 & 2.95 \\
\hline $\mathrm{N}-225$ & -2.58 & -2.76 & -40.10 & -0.98 \\
\hline
\end{tabular}

\section{Nitrogen acquisition:}

$\mathrm{N}$ accumulation in the grain and straw of wheat in the first and second seasons are shown in figure (4). Nitrogen accumulation in grains or straw was significantly increased with increasing $N$ application rates $\left(N_{1}-N_{3}\right)$ compared with the control treatment $\left(\mathrm{N}_{0}\right)$. Its accumulation in grain or straw at 
all treatments (N0I1- N3I4) significantly increased in a stepwise fashion and the values were higher at N3I1 followed by N3I2,N3I3,and N3I4 treatments than the values of other treatments in the two seasons (Fig.4). At $150 \mathrm{~kg}$ $\mathrm{N} \mathrm{ha}^{-1} \mathrm{~N}$ accumulation was lower than that at $225 \mathrm{~kg} \mathrm{~N}^{-h a^{-1}}$ at the same treatment of irrigation. Irrigation treatments, nitrogen application rates and their interactions significantly $(p<0.01)$ affected $N$ accumulation in grain or straw of wheat plants (Fig.4). These results were confirmed in the second season.

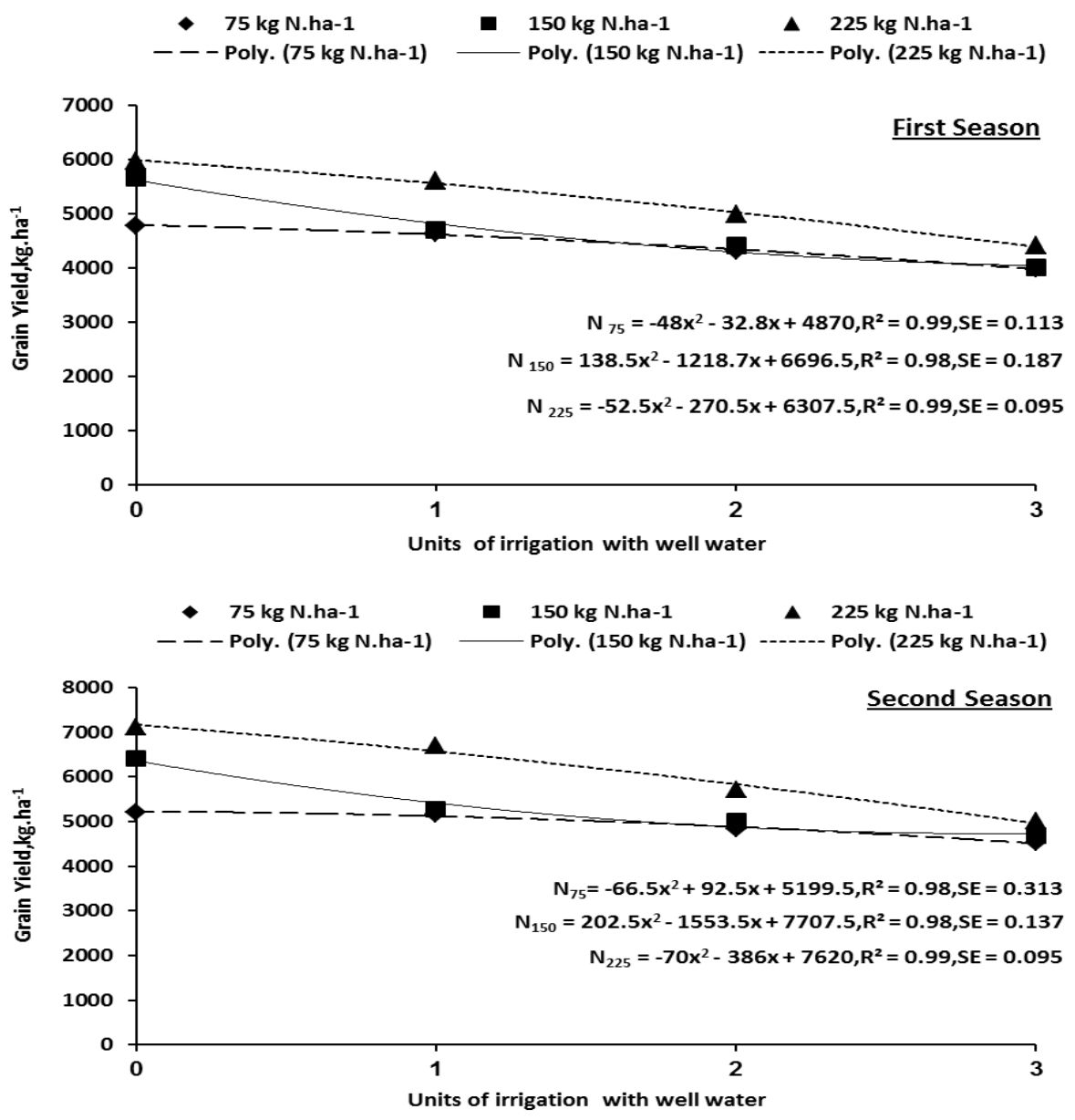

Fig.2: Polynomial quadratic models for grain of wheat plants grown on soil treated with different treatments of $\mathbf{N}$ fertilizer and irrigation in two successive seasons. One unit of irrigation = 2 times of irrigation with well water. 
Mahdy, A. M. et al.

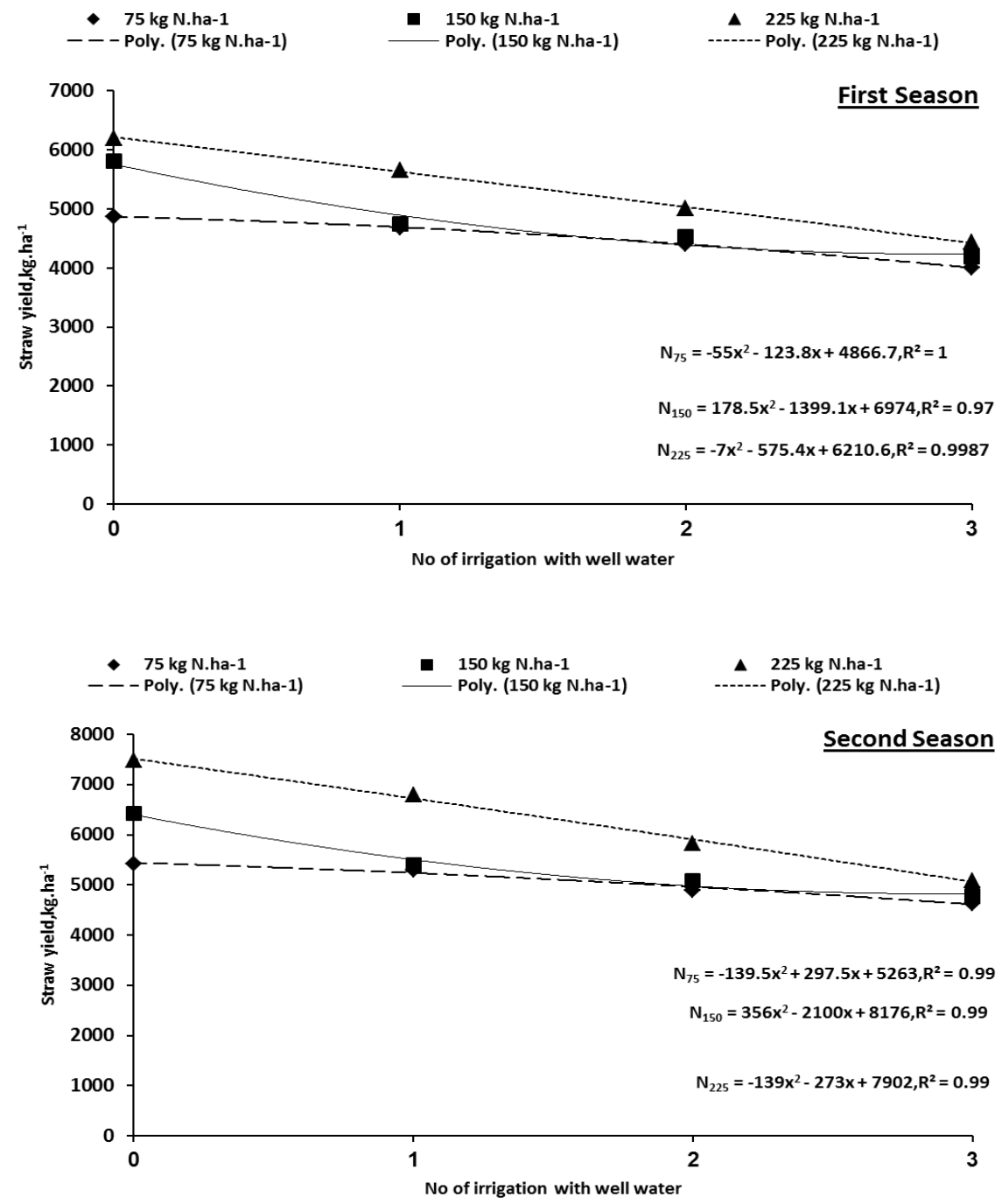

Fig.3: Polynomial quadratic models for straw of wheat crop grown on soil treated with different treatments of $\mathbf{N}$ fertilizer and irrigation in two successive seasons. One unit of irrigation $=2$ times of irrigation with well water. 


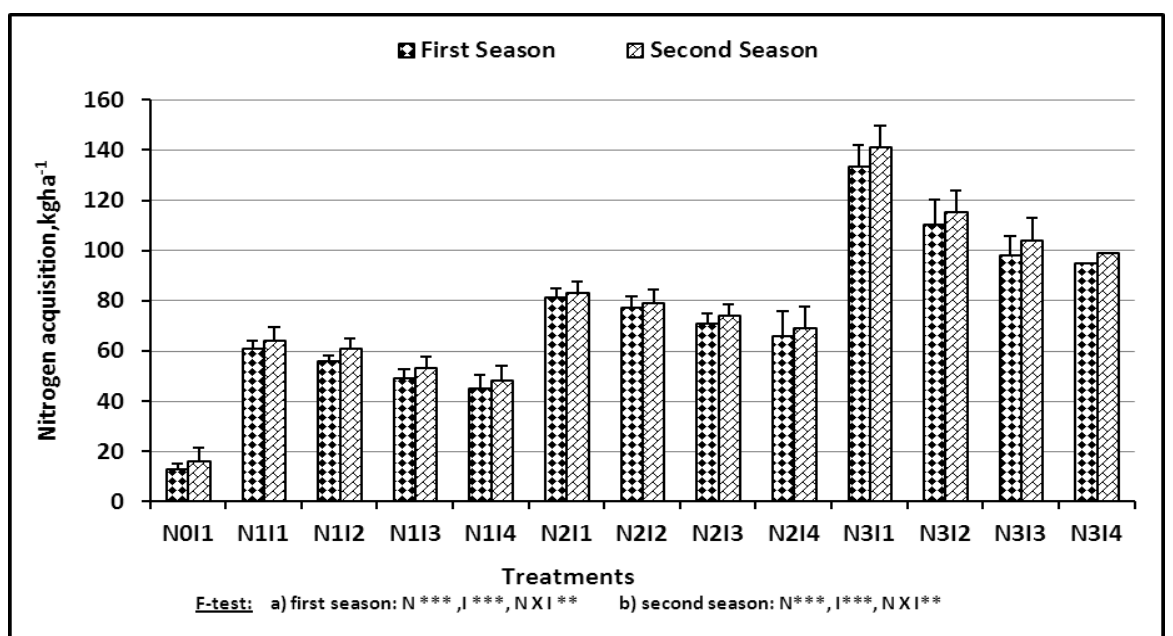

Fig.4: Nitrogen acquisition of wheat plants grown on soil treated with different treatments of $\mathrm{N}$ fertilizer and irrigation in two successive seasons.

\section{Nitrogen use efficiency(NUE):}

The mean values of NUE for grain yield were $63.73,61.87,57.49$ and $53.07 \mathrm{~kg}$ grain $\mathrm{Kg}^{-1} \mathrm{~N}$ for $75 \mathrm{~kg} \mathrm{~N}^{-1} \mathrm{ha}^{-1}$ at different irrigation treatments $\mathrm{N}_{1} \mathrm{l}_{1}$, $\mathrm{N}_{1} \mathrm{I}_{2}, \mathrm{~N}_{1} \mathrm{l}_{3}$, and $\mathrm{N}_{1} \mathrm{I}_{4}$, respectively for the first season (Table 4). The NUE decreased significantly with the increase in nitrogen application rate (LSD 0.05 $=0.58)$. At $150 \mathrm{~kg} \mathrm{~N} \cdot \mathrm{ha}^{-1}$ NUE significantly decreased with increasing number of irrigation with well water (Table 4).

Table (4): Nitrogen use efficiency (NUE) for grain and straw of wheat plants grown on soil treated with different treatments for two seasons.

\begin{tabular}{|c|c|c|c|c|}
\hline \multirow{3}{*}{ Treatments } & \multicolumn{4}{|c|}{ NUE,kg yield.kg fertilizer ${ }^{-1}$} \\
\hline & \multicolumn{2}{|c|}{ Grain } & \multicolumn{2}{|c|}{ Straw } \\
\hline & First season & Second season & First season & Second season \\
\hline N1I1 & $63.73(3.12)^{a}$ & $64.89(6.01)$ & $69.47(4.98)$ & $72.28(4.54)$ \\
\hline N112 & $61.87(2.36)$ & $62.49(2.77)$ & $68.47(3.58)$ & 70.67(3.81) \\
\hline $\mathrm{N} 1 \mathrm{l3}$ & $57.49(1.88)$ & 58.67(3.37) & $64.43(4.98)$ & $65.33(1.95)$ \\
\hline N114 & $53.07(2.86)$ & $53.33(2.46)$ & $60.28(4.54)$ & $61.76(2.93)$ \\
\hline $\mathrm{N} 2 \mathrm{I} 1$ & $37.69(0.44)$ & $38.67(3.12)$ & $42.67(2.22)$ & $42.88(3.44)$ \\
\hline $\mathrm{N} 212$ & $31.33(1.09)$ & $31.67(2.22)$ & $35.20(3.44)$ & $36.00(2.45)$ \\
\hline N2I3 & $29.33(0.98)$ & $30.15(1.43)$ & $33.33(2.43)$ & $33.87(2.88)$ \\
\hline N2/4 & $26.67(1.33)$ & $27.91(1.66)$ & $31.27(3.21)$ & $31.91(3.65)$ \\
\hline N3I1 & $26.53(0.98)$ & $27.56(1.65)$ & 31.64(1.99) & $33.29(4.00)$ \\
\hline N3I2 & $24.89(2.08)$ & $25.16(2.23)$ & $29.78(2.88)$ & $30.22(2.12)$ \\
\hline N3I3 & $22.13(1.11)$ & $22.22(1.08)$ & 25.33(3.32) & $25.92(2.67)$ \\
\hline N3/4 & 19.56(1.13) & $19.70(1.43)$ & $22.22(1.65)$ & $22.91(1.88)$ \\
\hline LSD 0.05 & 0.58 & 0.61 & 0.88 & 0.91 \\
\hline
\end{tabular}

${ }^{a}$ Means of three samples (SD). 
Mahdy, A. M. et al.

Similarly, NUE at $225 \mathrm{~kg} \mathrm{~N}$ ha ${ }^{-1}$ significantly reduced with the increase of number of irrigation with well water for the first season (Table 4).Also, for straw yield, NUE values were higher at $75 \mathrm{~kg} \mathrm{~N} . \mathrm{ha}^{-1}$ in comparison with $150 \mathrm{~kg} \mathrm{~N} \cdot \mathrm{ha}^{-1}$ and $150 \mathrm{~kg} \mathrm{~N} \cdot \mathrm{ha}^{-1}$ at all irrigation treatment for the first season (Table 4). The NUE values were significantly decreased (LSD $0.05=0.88$ ) with increasing in nitrogen application rates and the increase of number of irrigation with well water at the same $\mathrm{N}$ application rate (Table 4). The values of NUE for the straw yield were much greater than those of grain yield at the same irrigation treatment for first season (Table 4). It is clear that irrigation with well water, however, decreased NUE for grain or straw yields noticeably $(P \leq 0.05)$ at all $\mathrm{N}$ application rates (Table 4$)$. The reduction in NUE for grain or straw yields of wheat was much higher at treatment $I_{4}(6$ times well water , $4500 \mathrm{~m}^{3} \mathrm{ha}^{-1}+$ canal water, $1500 \mathrm{~m}^{3} \mathrm{ha}^{-1}$ ) than of that at treatment $\mathrm{I}_{2}\left(2\right.$ times well water, $1500 \mathrm{~m}^{3} \mathrm{ha}^{-1}+$ canal water, $\left.4500 \mathrm{~m}^{3} \mathrm{ha}^{-1}\right)$. The maximum NUE for grain yield $\left(63.73 \mathrm{~kg} . \mathrm{kg}^{-1} \mathrm{~N}\right)$ was observed with a $75 \mathrm{~kg}$ N.ha ${ }^{-1}$ and canal water-irrigated plots $\left(\mathrm{N}_{1} \mathrm{I}_{1}\right)$. In contrast, the minimum NUE

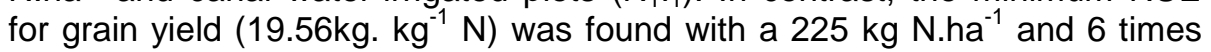
well water-irrigated plots $\left(\mathrm{N}_{3} \mathrm{l}_{4}\right)$. However, the maximum NUE for straw yield $\left(69.47 \mathrm{~kg} . ~ k g^{-1} \mathrm{~N}\right)$ was found with a $75 \mathrm{~kg} \mathrm{~N}^{-\mathrm{ha}^{-1}}$ and canal water-irrigated plots $\left(N_{1} l_{1}\right)$. In contrast, the minimum NUE for straw yield $\left(22.22 \mathrm{~kg}^{-1} \mathrm{~kg}^{-1} \mathrm{~N}\right)$ was recorded with a $225 \mathrm{~kg} \mathrm{~N}$.ha ${ }^{-1}$ and 6 times well water-irrigated plots $\left(\mathrm{N}_{3} \mathrm{l}_{4}\right)$. The mean nitrogen use efficiency(NUE) for grain and straw yields for the second season confirmed the results of the first season and were very close to each other (Table 4).

Agronomic efficiency(AE):

The rate of $225 \mathrm{~kg} \mathrm{~N} \mathrm{ha}^{-1}$ have the minimum agronomic efficiency (AE) among $N$ treatments, although the values of $A E$ was varied with $N$ treatments, but there was a tendency that $A E$ was decreased with increasing $\mathrm{N}$ fertilizer inputs(Table 5).

Table (5): Agronomic efficiency (AE) for grain of wheat plants grown on soil treated with different treatments for two seasons.

\begin{tabular}{|c|c|c|}
\hline \multirow[t]{2}{*}{ Treatments } & \multicolumn{2}{|c|}{ AE, kg yield.kg fertilizer ${ }^{-1}$} \\
\hline & First season & Second season \\
\hline N1I1 & $39.20(1.44)^{\mathrm{a}}$ & $39.88(2.55)$ \\
\hline $\mathrm{N} 112$ & $37.33(3.12)$ & $37.48(3.22)$ \\
\hline $\mathrm{N} 1 \mathrm{I3}$ & $32.96(3.55)$ & $33.65(2.88)$ \\
\hline $\mathrm{N} 114$ & $28.53(2.09)$ & $28.32(2.13)$ \\
\hline N2I1 & $25.43(1.33)$ & $26.16(1.12)$ \\
\hline $\mathrm{N} 2 \mathrm{I} 2$ & $19.07(1.08)$ & $19.16(2.09)$ \\
\hline $\mathrm{N} 213$ & $17.07(2.08)$ & $17.65(1.09)$ \\
\hline $\mathrm{N} 214$ & $14.40(1.12)$ & $15.41(1.67)$ \\
\hline N3I1 & $18.36(1.11)$ & $19.22(2.04)$ \\
\hline N3I2 & $16.71(1.09)$ & $16.82(1.33)$ \\
\hline N3I3 & $13.96(2.00)$ & $13.88(1.08)$ \\
\hline N314 & $11.38(0.98)$ & $11.36(0.88)$ \\
\hline LSD 0.05 & 0.71 & 0.81 \\
\hline
\end{tabular}

${ }^{a}$ Means of three samples (SD). 
However, the rate of $75 \mathrm{~kg} \mathrm{~N}^{-1}$ has the maximum agronomic efficiency (AE) among $\mathrm{N}$ treatments (Table 5). There was a significant effect of irrigation treatments on $A E$ in both seasons (LSD ${ }_{0.05}=0.71$ and 0.81 for first and second seasons respectively). Similarly, irrigation by well water decreased AE for grain yield noticeably $(P \leq 0.05)$ at all $\mathrm{N}$ application rates (Table 5). The reduction in $\mathrm{AE}$ for grain yield of wheat was much higher at 14 treatment than of that at 12 treatment. The maximum AE for grain yield $\left(39.20 \mathrm{~kg} \mathrm{~kg}^{-1}\right.$ N) was found with a $75 \mathrm{~kg} \mathrm{~N} \cdot \mathrm{ha}^{-1}$ and canal water-irrigated plots $\left(\mathrm{N}_{1} \mathrm{l}_{1}\right)$. In contrast, the minimum AE for grain yield $\left(11.38 \mathrm{~kg}^{-1} \mathrm{~kg}^{-1} \mathrm{~N}\right)$ was found with a $225 \mathrm{~kg} \mathrm{~N} \cdot \mathrm{ha}^{-1}$ and 6 times well water-irrigated plots $\left(\mathrm{N}_{3} \mathrm{l}_{4}\right)$. The mean agronomic efficiency (AE) for grain yield for the second season confirmed the results of first season and was very close to each other (Table 5).

\section{DISCUSSION}

Statistical analysis showed that the highly significant interaction between $\mathrm{N}$ and irrigation treatments indicated that the grain and straw yields of wheat plants were dependent on number of irrigation with well water and nitrogen application rate. The depressive effect of well water irrigation times altered with canal water on grain and straw yields could be attributed to other factors such as suppression of root growth (Robertson, 1985; Gajwska and Sktodowska, 2009), imbalance in plant nutrition because of salinity stress and water stress (Catalado et al., 1978) or a combination of these effects .Irrigation treatments and application of Nitrogen and their interaction significantly affected grain and straw yields of wheat plants (Fig.1). These results coincide with the results of Cartagena et al.,(1995) ; Hussain et al.,(1996); Schaan et al.,(2003); Choudhary et al.,(2006) and Wang et al.,(2010).

The values of coefficient of determination $\left(R^{2}\right)$ and standard error of estimate (SE) indicated that the relationships between units of irrigation with well water and grain or straw yields were successfully described with polynomial quadratic model.

Because the adverse effects of well water irrigation on yield and straw yields of wheat plants, the $I_{\max }$ were negative values at $Y_{\max }$ resulting in 225 $\mathrm{kg} \mathrm{N} . \mathrm{ha}^{-1}$ consequently would need more canal water application. These results coincided with the results of Fathi and Shama (2010).

Increasing nitrogen application rates at all irrigation treatments significantly increased $\mathrm{N}$ accumulation in grain or straw of wheat plant. Similar results were found by Abdel Magid et al. (1995) for wheat, Phillips et al. (2002) for bean, Clark et al. (1999) Colla et al. (2002) for tomato, Mahdy (2009) for maize, and Fathi and Shama(2010) for maize. The values of NUE for the straw yield were much greater than those of grain yield at the same irrigation treatment for first season. This was attributed with high straw yield at all irrigation water treatments (Table 4). 
The average values of $\mathrm{AE}$ ranged between 11.38 and $39.20 \mathrm{~kg}$ grain. $\mathrm{kg}^{-1}$ fertilizer for the first season and ranged from 11.36 to $39.88 \mathrm{~kg}$ grain. $\mathrm{kg}^{-1}$ for the second season (Table 5). These values were low as compared with the results of other's (Fang et al.2006; Yang et al. 2006). Optimization of water and $\mathrm{N}$ management requires knowledge of crop water requirements, $\mathrm{N}$ demands and the interaction between soil $\mathrm{N}$ dynamics and crop $\mathrm{N}$ uptakes. Determination of optimal irrigation regimes and $\mathrm{N}$ application rates is needed to increase $\mathrm{GY}$ and decrease the risk of $\mathrm{N}$ loss.

\section{Conclusion}

The optimum grain yield was achieved with application of $225 \mathrm{~kg} \mathrm{~N} \mathrm{ha}^{-1}$ in combination with full irrigation with canal water which can give the best grain or straw yields, $\mathrm{N}$ accumulation, NUE, and $\mathrm{AE}$ in both seasons. The recommendation should be for those farmers who use the upper range of the recommended $150-400 \mathrm{~kg} \mathrm{~N} \mathrm{ha}^{-1}$ which by MALR and accordingly can save about $25 \%$ of their $\mathrm{N}$ and $33 \%$ of their irrigation water application by adopting $225 \mathrm{~kg} \mathrm{~N} \mathrm{ha}{ }^{-1}\left(\mathrm{~N}_{3}\right)$ and irrigation with two times of well water as a supplemental irrigation combined with four times of canal water $\left(\mathrm{I}_{2}\right)$.

\section{REFERENCES}

Abdel-Magid, H.M, S.I.Abdel-Aal, R.K.Rabie, and R.E.Sabrah.1995.Chicken manure as a biofertilizer for wheat in the sandy soils of Saudi Arabia.J.Arid Environ.29:413-420

Bremner, J.M, and C.S. Mulvaney.1982.Nitrogen-Total, In: Page, A.L.,Miller, R.H. ,Keeney,D.R.(eds),Methods of Soil Analysis,. Am. Soc. of Agron., Madison, Wisconsin. Pp.595-623

Cartagena, M.C., A. Vallejo, J.A. Diez, A. Bustos, R.Caballero, and R. Roman. 1995. Effect of the type of fertilizer and source of irrigation water on $\mathrm{N}$ use in a maize crop. Field Crops Res. $44: 33-39$.

Catalado, D.A., T.R.Garland, and R.E.Widung .1978. Nickel in plant: I. Uptake kinetics using intact soybean seedling. Plant Physiol. 62:563-565.

Choudhary, O.P., B.S.Ghuman, A.S. Josan, and M.S.Bajwa.2006. Effect of altering irrigation with sodic and non-sodic waters on soil properties and sunflower yield.Agric.Wat.Manag.85(1-2):151-156.

Clark, M.S., W.R.Horwath, C. Shennan, K.M. Scow, W.T. Lantni, and H.Ferris.1999. Nitrogen, weeds and water as yield-limiting factors in conventional, low input, and organic tomato systems. Agric.Ecosyst. Environ. 73: 257-270

Colla, G., J.P.Mitchell,D.D. Poudel, and S.R. Temple.2002. Changes of tomato yield and fruit elemental composition in conventional,low input, and organic systems. J. Sustain. Agric. 20:53-67

Dag delen, N., E.Yilmaz, F.Sezgin, and T. Gu"rbu"z. 2006. Water-yield relation and water use efficiency of cotton (Gossypium hirsutum L.) and second crop corn (Zea mays L.) in western Turkey. Agric. Water Manage. 82: 63-85 
Day, P.R. ,1965. Particle fraction and particle size analysis, In: Black, A.C., Evans, D.D., Ensminger, L.E.,White, J.L.,Clark, F.E. (Eds.), Methods of soil analysis , Part I. American Society of Agronomy, Madison, Wisconsin, USA. pp: 545-566

English, M., and S.N.Raja. 1996. Perspectives on deficit irrigation. Agric. Water Manage. 32:1--14.

Evett, S.R., T.A.Howell, A.D. Schneider,D.R. Upchurch, and D.F. Wanjura.2000. Automatic drip irrigation of corn and soybean. In: Proceeding of the Fourth Decennial National Irrigation Symposium, November 14-16, Phoenix, AZ.

Evett, S.R., T.A.Howell,A.D. Schneider, D.F. Wanura, and D.R. Upchurch.2001. Water use efficiency regulated by automatic drip irrigation control. In: Proceeding of the International Irrigation Show, October 31-November 7, San Antonio, TX.

Fan, B.Q.,C.F. Hu, and J.L. Ping.1998. Effect of irrigation and fertilization on nitrate leaching in loamy fluvo-qauic soil.Plant Nutr Fertil Sci 4:16-21 (In Chinese)

Fang, Q.X., Q.Yu, and E.L. Wang .2006. Soil nitrate accumulation, leaching and crop nitrogen use as influenced by fertilization and irrigation in intensive wheat maize double cropping system in the North China Plain. Plant Soil 284:335-350

Fathi, N.O., and M.A.Shama . 2010. Yield response of corn to supplemental irrigation with well water and nitrogen fertilization in a semi-arid environment. Minufiya. J. Agric. Res.,35No.4(2) : 1573-1585.

Fredrick, J.R., and J.J.Camberato.1995a. Water and nitrogen effects on winter wheat in the Southeastern Central Plain: I. Grain yield and kernel traits. Agron J 87:521-526

Fredrick, J.R., and J.J.Camberato.1995b. Water and nitrogen effects on winter wheat in the Southeastern Central Plain: physiological responses. Agron J 87:527-533

Gajewska, E., and M. Skłodowska .2009. Nickel-induced changes in nitrogen metabolism in wheat shoots. J. Plant Physiol.166:1034-1044.

Howell, T.A., J.A.Tolk, A.D.Scheider, and S.R. Evett.1998. Evapotranspiration, yield, and water use sfficiency of corn hybrids differing in maturity. Agron. J 90:3-9

Howell, T.A.2001. Enhancing water use efficiency in irrigated agriculture. Agron. J. 93: 281-289

Hussain, G., A.A.Al-Jaloud, and S.Karimulla.1996. Effect of treated effluent irrigation and nitrogen yield and nitrogen use efficiency of wheat. Agric. Water. Manage. 30: 175-184.

Jones, J.B.2001. Laboratory Guide of Conducting Soil Tests and Plant Analysis.CRC Press. New York, Washington D.C., USA.

Ju, X.T.,X.J. Liu, and F.S. Zhang .2003. Accumulation and movement of NO3--N in soil profile in winter wheat-summer maize rotation system. Acta Pedo Sin 40:538-546 (In Chinese) 
Ju, X.T., X.J.Liu, and F.S. Zhang .2004. Nitrogen fertilization, soil nitrate accumulation and policy recommendations in several agricultural regions of China. Am Biol Teach 33:278-283

Katterer, T., A.C.Hansson, and O. Andren.1993. Wheat root biomass and nitrogen dynamics - effects of daily irrigation and fertilization. Plant Soil 151:21-30

Knudsen, D.,G.A. Peterson, and P.F.Pratt.1982. Lithium,sodium and potassium. In :Page, A.L.,Miller R.H., Keeney, D.R.(eds): Methods of soil analysis, Am. Soc. Agron., Madison, Wisconsin, USA. p225-245

Li, S.J., D.X.Zhou, and J.M. Li.2001. Effect of different nitrogen application on yield, nitrogen distribution and utilization in winter wheat under soil water stress. Acta Agr Boreali-Sin 16:86-91 (In Chinese)

Liu, X.J., X.T.Ju, and F.S. Zhang.2001. Effect of urea application as basal fertilizer on inorganic nitrogen in soil profile. J China Agric Univ 6,6368 (In Chinese)

Liu, X.J., X.T.Ju, and F.S. Zhang .2003. Nitrogen dynamics and budgets in a winter wheat-maize cropping system in the North China Plain. Field Crop Res 83:111-124

Ma, J.Z., X.S.Wang,and W.M. Edmunds. 2005. The characteristics of groundwater resources and their changes under the impacts of human activity in the arid North-West China-a case study of the Shiyang River Basin. J Arid Environ 61:277-295

Mahdy, A.M.2009. Combination effects of organic and mineral fertilization on corn(Zea mays) macronutrient concentrations and yield.Alex.Sci.Exch.J.30:108-120

Nelson, D.W., and L.E.Sommers.1982. Total Carbon, Organic Carbon and Organic Matter., In:Page, A.L.,Miller, R.H., Keeney, D.R.(eds), Methods of Soil Analysis, Am. Soc. Agron., Madison, Wisconsin, USA. pp: 539-549.

Nelson, R.E. 1982. Carbonate and Gypsum., In: Page, A.L.,Miller, R.H., Keeney, D.R.(eds),Methods of Soil Analysis, Am. Soc. Agron., Madison, Wisconsin, USA. pp: 181-197.

Norwood, C.A. 2000. Water use and yield of limited-irrigated and dry land corn. Soil Sci Soc Am J 64:365--370

Oktem, A., M.Simsek, and A.G.Oktem.2003. Deficit irrigation effects on sweet corn (Zea mays saccharata Sturt) with drip irrigation system in a semiarid region I. Water-yield relationship. Agric. Water Manage. 61:63-74

Olsen, S.R., and L.E.Sommers.1982. Phosphorus., In: Page, A.L.,Miller, R.H., Keeney, D.R.(eds), Methods of Soil Analysis, Am. Soc. Agron., Madison, Wisconsin, USA. pp:403-427

O'Neill, P.M., J.F.Shanahan, and J.S. Schepers.2004. Agronomic responses of corn hybrids from different areas to deficit and adequate level of water and nitrogen. Agron J 96:1660-1667

Ottman, M.J., and N.V.Pope.2000. Nitrogen fertilizer movement in the soil as influenced by nitrogen rate and timing in irrigated wheat. Soil Sci Soc Am J 64:1883-1892 
Pandey, R.K., J.W.Maranville, andA. Admou.2001. Tropical wheat response to irrigation and nitrogen in a Sahelian environment.I. Grain yield, yield components and water use efficiency. Eur. J. Agron. 15:93-105

Phillips, S.B., G.L.Mullins, and S.J. Donohue.2002. Changes in snap bean yield, nutrient composition, and soil chemical characteristics when using broiler litter as fertilizer source. J. Plant Nutr. 25:1607-1620

Rhoades, J.D.1982. Cation Exchange Capacity., In: Page, A.L.,Miller, R.H., Keeney, D.R.(eds), Methods of Soil Analysis, Am. Soc. Agron., Madison, Wisconsin, USA. pp: 149-157

Richards, L.A.1954. Diagnosis and Improvement of Saline and Alkaline Soils. USDA Handbook 60.US Government Printing Office, Washington D. C.

Robertson, A.I.1985. The poisoning of roots of Zea mays by nickel ion and the protection afforded by magnesium and calcium. New Physiol:100:179-189

SAS Institute,1994. SAS/STAT User's Guide. Version 6.4th Ed. SAS Inst., Cary, N.C.

Schaan, C.M., D.A. Devtt, R.L.Morris, and L.Clark.2003. Cyclic irrigation using a shallow saline aquifer.Agron.J.95:660-667.

Sexton, B.T., J.F.Moncrief, and C.J. Rosen.1996. Optimizing nitrogen and irrigation inputs for corn based on nitrate leaching and yield on a coarse-textured soil. J Environ Qual 25:982-992

Su, Y.Z., Z.H.Zhang, and R. Yang.2007. Amount of irrigation and nitrogen application for maize grown on sandy farmland in the marginal oasis in the middle of Heihe River Basin.Acta Agr. Sinic 33:2007-2015

Tan, K.H.1996. Soil Sampling, Preparation, and Analysis. Marcel Dekker, Inc. New York. Basel. Hong Kong.

USEPA (US Environmental Protection Agency),1993. Standard for the use and disposal of sewage sludge. Office of Water, EPA-822/ R-96-003. Environmental Protection Agency, Washington D. C.

Wang, Q., F.Li, L.Zhao, E.Zhang, S.Shi, W.Zhao, W.Song, and M.M.Vance.2010. Effects of irrigation and nitrogen application rates on nitrate nitrogen distribution and fertilizer nitrogen loss, wheat yield and nitrogen uptake on a recently reclaimed sandy farmland. Plant Soil 337:325-339.

Yang, S.M., S.S.Malhi, and J.R. Song.2006. Crop yield, nitrogen uptake and nitrate-nitrogen accumulation in soil as affected by 23 annual applications of fertilizer and manure in the rainfed region of Northwestern China. Nutr Cycl Agroecosys 76:81-94

Yang, R., and Y.Z.Su. 2008. Groundwater nitrate pollution in the oasis agricultural area in the middle reaches of Heihe River. Northwest China J Glaciol Geocryol 30:983-990 (In Chinese)

Yin, F., B.Fu, and R.Mao.2007. Effects of nitrogen fertilizer application rates on nitrate nitrogen distribution in saline soil in the Hai River Basin, China. J Soil Sediment 7:136-142 
Mahdy, A. M. et al.

Zhang, W.L., Z.X.Tian, and N. Zhang.1995. Investigation of nitrate pollution in ground water due to nitrogen fertilization in agriculture in Northern China. Plant Nutr Fertil Sci 1:80-87 (In Chinese)

Zhang, W.L., Z.X.Tian, ans N. Zhang.1996. Nitrate pollution of groundwater in Northern China. Agric Ecosyst Environ 59:223-231

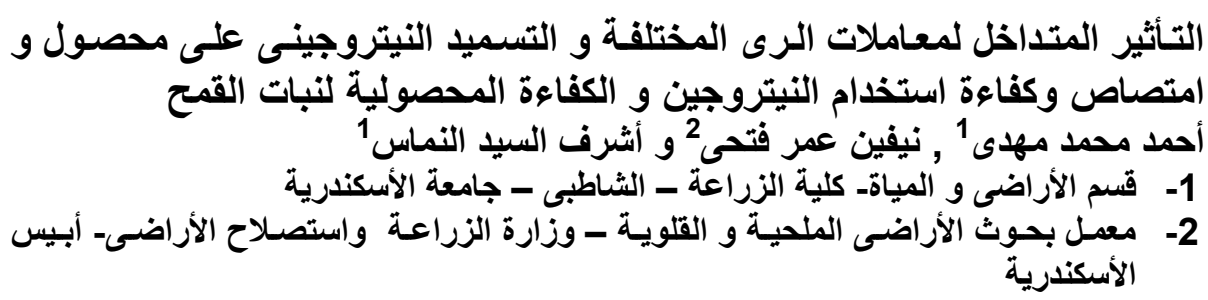

أجريت دراسـة حقلية بهدف دراسـة التأثير المتداخل لمعساملات الرى المختلفة و التسميد

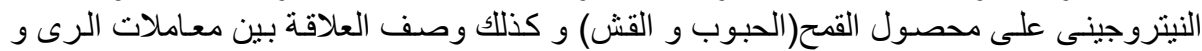

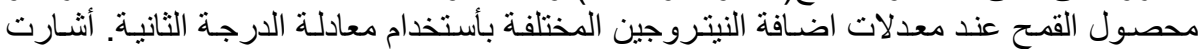

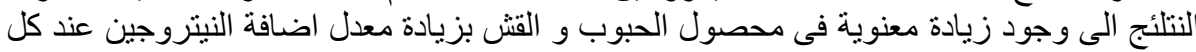

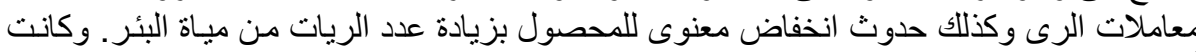

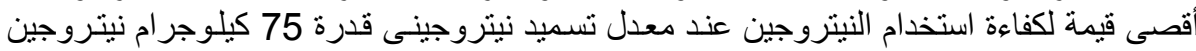

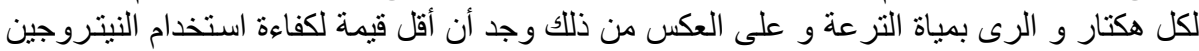

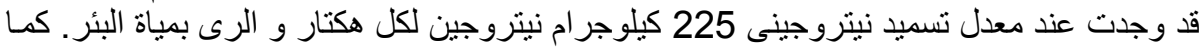

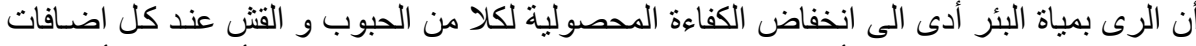

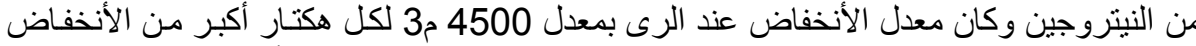

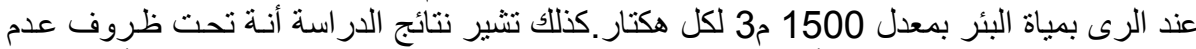

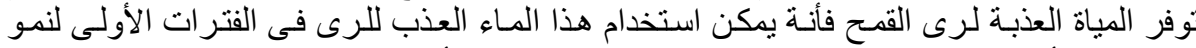

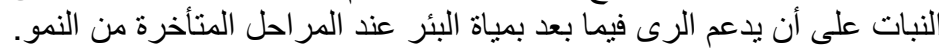

كلية الزراعة - جامعة المنصورة كلية الزراعة - جامعة - جامعة الاسكندرية

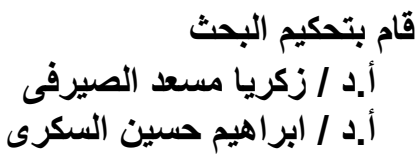

